\title{
Justice and Nonverbal Communication in a Post-pandemic World: An Evidence-Based Commentary and Cautionary Statement for Lawyers and Judges
}

\author{
Vincent Denault ${ }^{1,2}$ - Miles L. Patterson ${ }^{3}$ \\ Published online: 9 August 2020 \\ (c) Springer Science+Business Media, LLC, part of Springer Nature 2020
}

\begin{abstract}
On 11 March 2020, the World Health Organization officially declared COVID-19 a pandemic. The new physical distancing rules have had many consequences, some of which are felt throughout the justice system. Courts across the world limited their operations. Nonetheless, given that justice delayed is justice denied, many jurisdictions have turned to technologies for urgent matters. This paper offers an evidence-based comment and caution for lawyers and judges who could be inclined, for concerns such as cost and time saving, to permanently step aside from in-person trials. Using nonverbal communication research, in conjunction with American and Canadian legal principles, we argue that such a decision could harm the integrity of the justice system.
\end{abstract}

Keywords Trials · Witnesses · Nonverbal communication · Facial expressions $\cdot$ Hand gestures $\cdot$ COVID-19

\section{Introduction}

On 11 March 2020, the World Health Organization officially declared COVID-19 a pandemic. The resulting new physical distancing rules have had many consequences, some of which are felt throughout the justice system, a pillar of democracy for societies based on the rule of law. Courts across the world limited their operations. Nonetheless, given that justice delayed is justice denied, many jurisdictions have turned to technologies for urgent matters. The use of phone and computer applications such as Skype or Zoom to conduct trials instead of the usual in-person format raises concerns similar to those identified by legal scholars with regards to trials by videoconference, such as dehumanizing defendants (Eagly 2015; Salyzyn 2012). Importantly, the use of such applications also raises a number

Vincent Denault

vincent.denault@umontreal.ca

1 Department of Communication, Université de Montréal, 90 Avenue Vincent-d'Indy, Outremont, QC H2V 2S9, Canada

2 Centre for Studies in Nonverbal Communication Sciences, Montreal, Canada

3 Department of Psychological Sciences, University of Missouri-St. Louis, St. Louis, USA 
of commonly ignored issues related to the role of nonverbal communication during in-person exchanges. Because legal scholars and practitioners are rarely trained in research-based principles of nonverbal communication (with some even attending pseudoscientific lie detection seminars, Denault et al. 2020), there can be serious threats to the proper course of court proceedings. This paper offers an evidence-based comment and caution for lawyers and judges who could be inclined, for concerns such as cost and time saving, to permanently step aside from in-person trials.

First, we address the faulty historical premise that the role of nonverbal communication during trials is simply to determine who is lying and who is telling the truth. Second, we explain why a fair trial and a meaningful application of the presumption of innocence require, among other things, that lawyers and triers of facts be able to adequately see patterns of witnesses' nonverbal communication, not just their facial expressions. Finally, we call upon lawyers and judges to closely work with nonverbal communication scholars and, in turn, nonverbal communication scholars concerned about the actual state of democracy to address more directly the dynamics of courts and courtrooms.

\section{The History and Criticism of Demeanor Evidence}

The use of nonverbal communication during trials goes back hundreds, if not thousands of years, whether it was to identify individuals who wanted to poison others by observing, among other things, the color of their face (Troville 1939; Wise 1845), or to ascertain the guilt or innocence of suspects through "Judgments of God" by examining scars resulting from physical procedures (Ford 2006; Kleinmuntz and Szucko 1984). To this day, in American and Canadian justice systems, for example, triers of facts (i.e., judges in bench trials or jurors in jury trials) are legally authorized to consider witness demeanor. According to the United States Supreme Court, triers of facts may judge a witness "by his demeanor upon the stand and the manner in which he gives his testimony whether he is worthy of belief" (Mattox v. United States 1895, p. 242-243; see also Coy v. Iowa 1988). Likewise, the Supreme Court of Canada asserted that triers of facts have "the great advantage of watching the demeanor of all who testify" (P. (D.) v. S. (C.), 1993, p. 192). More recently, the Supreme Court of Canada argued that facial expressions were important to conduct effective cross-examinations by lawyers and witness credibility assessments by triers of facts:

Non-verbal communication can provide the cross-examiner with valuable insights that may uncover uncertainty or deception, and assist in getting at the truth. Covering a witness's face may also impede credibility assessment by the trier of fact, be it judge or jury. (R. v. N. S. 2012, p. 743-744)

In keeping with the views of the United States and Canada's highest courts, triers of facts regularly turn to witness demeanor for credibility assessment. This approach, however, has been severely criticized (e.g., Blumenthal 1993; Minzner 2008; Timony 2000; Wellborn 1990). For example, meta-analyses have shown that nonverbal cues to detect lies are largely faint and unreliable and that lie detection accuracy using common visual nonverbal cues rarely exceeds chance (Bond and DePaulo 2006, 2008; DePaulo et al. 2003; Leach et al. 2016; Snook et al. 2017; Vrij and Turgeon 2018). Furthermore, judges in bench trials and jurors in jury trials hold erroneous beliefs about the validity of nonverbal cues to detect lies (e.g., Denault and Dunbar 2019; Heath 2009; Strömwall and Granhag 2003). For example, the popular belief that liars act nervously is not supported by empirical evidence 
(The Global Deception Research Team 2006; Vrij 2008). These criticisms might seem consistent with limiting in-person trials and replacing them with phone and computer applications on a regular basis. We contend, however, that such a position would be misguided.

\section{Flawed Arguments Against the Importance of Witness Demeanor}

There should be no doubt about the importance, if not the necessity, of recognizing the dangers of systemic biases and stereotypes in courtrooms. Rape myths, for example, distort the outcome of trials and allow perpetrators to escape justice (Dinos et al. 2015; Leverick 2020). The same holds for erroneous beliefs about the validity of nonverbal cues to detect lies. Indeed, as Denault and Dunbar (2019) point out, expectations about how honest and dishonest witnesses are supposed to behave influence witness credibility assessments. And according to the Supreme Court of Canada, "credibility is an issue that pervades most trials, and at its broadest may amount to a decision on guilt or innocence" (R. v. Handy 2002, p. 951).

Arguing against in-person trials, however, because common visual nonverbal cues to detect lies are largely faint and unreliable fails to recognize that many vocal and verbal cues to deception are also largely faint and unreliable (DePaulo et al. 2003). In addition, novel lie detection techniques using verbal cues, and promoted as alternatives to nonverbal cues (Snook et al. 2017; Vrij and Fisher 2016; Vrij and Granhag 2012; Vrij and Turgeon 2018), were developed for investigative interviews, not for real-life court proceedings (Denault and Jupe 2018; Denault et al. 2019a). As Denault and Dunbar (2019) argue, those techniques ignore characteristics of adversarial justice systems, including the more passive roles of judges and jurors. In addition, the nature of questions asked by lawyers during reallife examinations and cross-examinations are often different from those in experimental settings. The same holds for the answers of witnesses in courtrooms. As Scheppele (1989) points out,

Stories may diverge, then, not because one is true and another false, but rather because they are both self-believed descriptions coming from different points of view informed by different background assumptions about how to make sense of events. (p. 2082)

Furthermore, arguing against in-person trials because of erroneous beliefs about the validity of nonverbal cues to detect lies overlooks the fact that triers of facts also hold erroneous beliefs about the validity of vocal and verbal cues to deception, and that "lawyers performing cross-examination can draw witnesses into these cues to make them appear nervous and untruthful" (Denault et al. 2019a, p. 5; see also Denault and Dunbar 2017, 2019; Denault et al. 2019b; Strömwall and Granhag 2003). For better or worse, common sense is an integral part of judicial reasoning (Burns 2016; Cochran 2013; Friedland 1989). Judges in bench trials and jurors in jury trials use it for more than evaluating demeanor and are authorized to do so in making their decisions. As the Supreme Court of Canada notes, "credibility must always be the product of the judge or jury's view of the diverse ingredients it has perceived at trial, combined with experience, logic and an intuitive sense of the matter" (R. v. Marquard 1993, p. 248). In other words, the belief that ignoring faces and bodies will result in more rational judicial reasoning, without further adverse consequences, is not supported by empirical 
evidence. In fact, the importance of nonverbal communication during trials involves much more than simply characterizing witnesses as liars or truth-tellers.

\section{The Role of Nonverbal Communication During Trials}

Although crime drama television series, such as Lie To Me, have brought the topic of deception detection to the forefront in recent years (Serota 2014), nonverbal communication has been subject to thousands of peer-reviewed publications since the 1960s. Scholars across several academic disciplines have shown that, during in-person exchanges, our face and body serve a variety of functions beyond lie detection (Patterson 1983, 2011). As Hall et al. (2019) emphasize,

The breadth of topics that relate to NVC [nonverbal communication] is quite wide, in accordance with its many functions, which include displaying affect (such as anxiety or happiness), revealing attitudes (such as interest, prejudice, or intimacy), regulating interaction (such as taking turns or directing attention), managing impressions (such as by presenting oneself as competent or brave), revealing physical and mental conditions (such as pain or mental disorders), and exerting interpersonal control (as in displaying dominance). (p. 273)

Nonverbal communication refers to the sending and/or receiving of information through a variety of environmental cues, appearance features, and nonverbal cues and behaviors such as facial expressions, gaze patterns, postures, and body movements (Hall and Knapp 2013; Manusov and Patterson 2006; Matsumoto et al. 2016; Patterson 2011). Thus, the design and arrangement of courts and courtrooms, as well as the appearance features and the nonverbal cues and behaviors of judges, jurors, court clerks, security guards, defendants, witnesses, and lawyers, all affect the course of court proceedings. Their facial expressions, gaze patterns, postures, and body movements convey interpersonal and social information, such as their appraisals, concerns, and dispositions about a situation. In addition, these nonverbal cues and behaviors signal their behavioral intentions, and create impressions among those present in courtrooms and in public observing them, without a single word being uttered (Hall et al. 2019; see also Blanck et al. 1990; Remland 1994; Searcy et al. 2004).

In the case of bench and jury trials, the opportunities to observe nonverbal behaviors include the following: (1) when judges talk to witnesses and lawyers; (2) when witnesses testify; (3) when lawyers examine and cross-examine witnesses; (4) when lawyers make their opening and closing arguments; and (5) when lawyers and clients talk. Moreover, "third-party" expressive reactions by judges, jurors, defendants, witnesses, and lawyers to other interaction participants precipitate evaluations about the course of events. In other words, nonverbal communication, which includes much more than just the speaker's face, provides participants feedback to coordinate and manage in-person exchanges on a moment-by-moment basis in the service of participants' goals (Harrigan 1985, 2005; Patterson 2019; Rossano 2012). As Patterson (1995) describes,

... interactants simultaneously act with, and form impressions of, their partners. Thus, individuals are encoding information, feelings, intentions, scripts, or other reactions into behavioral expression while, at the same time, decoding the behavior of the partner and experiencing feedback from their own behavior. (p. 6) 
Very few nonverbal cues and behaviors have definite signification. As reiterated by Hall et al. (2019), "contextual factors involving encoders' intentions, their other verbal and nonverbal behaviors, other people (who they are and their behavior), and the setting will all affect meaning" (p. 272). In addition, how people understand and adapt to facial expressions, gaze patterns, postures, and body movements often happen outside of awareness (Patterson 2019), including through nonconscious mimicry (also known as the "chameleon effect"), that is, the automatic tendency to imitate the behavior of others (Chartrand and Bargh 1999; Hess and Fischer 2014). Nonconscious mimicry also has many other prosocial consequences between interaction participants, including the increase in accuracy of emotion perception, in displays of helpful behaviors, and in feelings of liking, empathy, and trust (Chartrand and Lakin 2013).

Although facial expressions, gaze patterns, postures, and body movements have garnered much attention (Plusquellec and Denault 2018), "a large body of research shows that hand gestures produced during speech are, along with the words, part of an integrated speech production system" (Hall et al. 2019, p. 272). For example, in a variety of contexts, the speaker's hand gestures can reduce demand on working memory and facilitate speech production (e.g., Cook and Fenn 2017; Cook et al. 2012; Krauss et al. 2000; Ping and Goldin-Meadow 2010), provide information on their own, and improve the listener's understanding of the speaker's verbal information (e.g., when the speaker's verbal information is equivocal) (Goldin-Meadow and Alibali 2013). In addition, listeners producing hand gestures themselves can enhance their understanding of the speaker's speech (Dargue et al. 2019; Hostetter 2011).

Finally, although the use of phone and computer applications such as Skype or Zoom limit the breadth of view and the ability of lawyers and triers of facts to choose their focus, it could be argued that the behavioral information is simply different. For example, contrary to in-person trials where judges in bench trials and jurors in jury trials may be many feet away, facial characteristics of witnesses could be viewed better on phone and computer screens. This could introduce, however, other concerns about the course of court proceedings. When the focus is primarily on the face, for example, the potential impact of facial characteristics increases. This is not to be taken lightly. Facial characteristics can adversely influence the evaluation of evidence and the sentence of defendants, even when they are subject to the death penalty (Porter and ten Brinke 2009; Porter et al. 2010; Wilson and Rule 2015, 2016).

Our brief overview describes the pervasive and complex role of nonverbal communication during in-person exchanges, including those in courtrooms. Because one of the main functions of judges in bench trials and jurors in jury trials is to understand witnesses, and to ascertain the sometimes complex facts to which the law will apply (Bell 2013; Denault et al. 2019a; Denault and Jupe 2018; Paciocco 2010), the critical role of nonverbal communication in courtrooms should be weighed before limiting inperson trials and replacing them with phone and computer applications on a regular basis. The Supreme Court of Canada emphasized that "credibility is an issue that pervades most trials, and at its broadest may amount to a decision on guilt or innocence" (R. v. Handy 2002, p. 951) and that "effective cross-examination is integral to the conduct of a fair trial and a meaningful application of the presumption of innocence" (R. v. N. S. 2012, p. 743; see also Mattox v. United States 1895). Permanently moving away from in-person trials could interfere with the conduct of effective cross-examinations by lawyers and witness credibility assessments by triers of facts, and ultimately, harm the integrity of the justice system. 


\section{The Use of Phone and Computer Applications: A Call for Caution}

This paper offers an evidence-based comment and caution for lawyers and judges who could be inclined, for concerns such as cost and time saving, to permanently step aside from in-person trials. First, we addressed the faulty historical premise that the role of nonverbal communication during trials is simply to determine who is lying and who is telling the truth. Second, we explained why a fair trial and a meaningful application of the presumption of innocence require, among other things, that lawyers and triers of facts be able to adequately see the patterns of witnesses' nonverbal communication, not just their facial expressions. As we have noted, nonverbal cues can also be misleading and result in systematic biases and stereotypes.

There should be no doubt that during the COVID-19 pandemic, technology allows triers of facts to listen to witnesses, albeit imperfectly, and to resolve urgent disputes (e.g., Abruzzese 2020; Boisvert 2020; Burns 2020; Gerstein 2020; Ibrahim 2020; Mathieu 2020; McLachlin 2020; Reynolds 2020; Schmitz 2020). And it is evident that in some delicate situations, technology (e.g., CCTV) can facilitate the testimony of vulnerable individuals, such as rape victims and child witnesses (e.g., Bennett 2003; Hamilton et al. 2017; Kenniston 2015). These accommodations are also recognized by the US Supreme Court and the Supreme Court of Canada (Maryland v. Craig 1990; R. v. J. Z. S. 2010).

Nevertheless, before extolling the merits of phone and computer applications, the multiple functions of nonverbal communication should be carefully considered, as should other concerns raised by experts. Legal scholars have written about various adverse consequences of trials by videoconference (e.g., Cimino et al. 2014; Diamond et al. 2010; Donoghue 2017; Federman 2006; Marr 2013; Poulin 2004; Walsh and Walsh 2008). These consequences not only include dehumanizing defendants (Eagly 2015; Salyzyn 2012), but also compromising their right to effective counsel assistance (Johnson and Wiggins 2006), and hindering the image and the role of judges, the symbolic function of courthouses, and the law's legitimacy and authority (Rowden 2015; Rowden and Wallace 2018; Salyzyn 2012). Concerns raised by practitioners should also not be overlooked. For example, in the absence of in-person trials, it is difficult, if not impossible, to know if someone not visible on the screen is coaching witnesses, or if witnesses are consulting unauthorized documents to assist in their examination and cross-examination (Bermann 2020). In addition, inadequate access to computers and high-speed internet could lead to severe equity problems (Offit 2020).

In light of all of these issues, lawyers and judges can closely work with nonverbal communication scholars in the pursuit of improving the administration of justice in a post-pandemic world. The steadily growing body of research-based principles of nonverbal communication can assist in establishing evidence-based practices for in-person trials. And nonverbal communication scholars concerned about the actual state of democracy might address more directly the dynamics of courts and courtrooms, as well as conducting further collaborative research on these matters. In spite of the challenges of researching justice systems, such efforts provide an opportunity for nonverbal communication scholars to contribute to the betterment of society.

Acknowledgements The authors would like to thank Norah E. Dunbar and Fanny A. Ramirez for their constructive comments on an earlier version of this manuscript. 


\section{References}

Abruzzese, R. (2020). New York City Family Court is hearing cases in five virtual courtrooms. Brooklyn Daily Eagle. Retrieved May 19, 2020, from https://brooklyneagle.com/articles/2020/04/20/newyork-city-family-court-is-hearing-cases-in-five-virtual-courtrooms/.

Bell, E. (2013). An introduction to judicial fact-finding. Commonwealth Law Bulletin, 39(3), 519-552.

Bennett, K. J. (2003). Legal and social issues surrounding closed-circuit television testimony of child victims and witnesses. Journal of Aggression, Maltreatment \& Trauma, 8, 233-271.

Bermann, G. A. (2020). Dispute resolution in pandemic circumstances. In K. Pistor (Ed.), Law in the time of Covid-19 (pp. 167-174). New York: Columbia Law School.

Blanck, P., Rosenthal, R., Hart, A. J., \& Bernieri, F. (1990). Measure of the judge: An empirically-based framework for exploring trial judges' behavior. The Iowa Law Review, 75(3), 653-684.

Blumenthal, J. A. (1993). A wipe of the hands, a lick of the lips: The validity of demeanor evidence in assessing witness credibility. Nebraska Law Review, 72(4), 1157-1204.

Boisvert, Y. (2020). Changer pour rester les mêmes [Change to stay the same]. Retrieved May 19, 2020, from https://www.lapresse.ca/covid-19/202004/23/01-5270698-changer-pour-rester-les-memes.php.

Bond, C. F., \& DePaulo, B. M. (2006). Accuracy of deception judgments. Personality and Social Psychology Review, 10(3), 214-234.

Bond, C. F. Jr., \& DePaulo, B. M. (2008). Individual differences in judging deception: Accuracy and bias. Psychological Bulletin, 134(4), 477-492.

Burns, I. (2020). Culture shift will be lasting legacy of COVID-19 pandemic, B.C. chief justice says. The Lawyer's Daily. Retrieved May 19, 2020, from https://www.thelawyersdaily.ca/articles/19023/ culture-shift-will-be-lasting-legacy-of-covid-19-pandemic-b-c-chief-justice-says.

Burns, K. (2016). Judges, 'common sense' and judicial cognition. Griffith Law Review, 25(3), 319-351.

Chartrand, T. L., \& Bargh, J. A. (1999). The chameleon effect: The perception-behavior link and social interaction. Journal of Personality and Social Psychology, 76(6), 893-910.

Chartrand, T. L., \& Lakin, J. L. (2013). The antecedents and consequences of human behavioral mimicry. Annual Review of Psychology, 64, 285-308.

Cimino, E. F., Makar, Z., \& Novak, N. (2014). Charm city televised \& dehumanized: How CCTV bail reviews violate due process. University of Baltimore Law Forum, 45(1), 57-104.

Cochran, P. (2013). Common sense and the legal judgment: Community knowledge, political power and rhetorical practice. Doctoral Thesis, University of British Columbia. Retrieved May 19, 2020, from http://hdl.handle.net/2429/45300.

Cook, S. W., \& Fenn, K. M. (2017). The function of gesture in learning and memory. In R. B. Church, M. W. Alibali \& S. D. Kelly (Eds.), Why gesture? How the hands function in speaking, thinking and communicating (pp. 129-153). Amsterdam: John Benjamins.

Cook, S. W., Yip, T. K., \& Goldin-Meadow, S. (2012). Gestures, but not meaningless movements, lighten working memory load when explaining math. Language and Cognitive Processes, 27(4), 594-610.

Coy v. Iowa, 487 U.S. 1012 (1988).

Dargue, N., Sweller, N., \& Jones, M. P. (2019). When our hands help us understand: A meta-analysis into the effects of gesture on comprehension. Psychological Bulletin, 145(8), 765-784.

Denault, V., \& Dunbar, N. E. (2017). Nonverbal communication in courtrooms: Scientific assessments or modern trials by ordeal? The Advocates' Quarterly, 47(3), 280-308.

Denault, V., \& Dunbar, N. E. (2019). Credibility assessment and deception detection in courtrooms: Hazards and challenges for scholars and legal practitioners. In T. Docan-Morgan (Ed.), The Palgrave handbook of deceptive communication (pp. 915-936). Basingstoke: Palgrave Macmillan.

Denault, V., Dunbar, N. E., \& Plusquellec, P. (2019a). The detection of deception during trials: Ignoring the nonverbal communication of witnesses is not the solution-A response to Vrij and Turgeon (2018). The International Journal of Evidence and Proof, 24(1), 3-11.

Denault, V., \& Jupe, L. (2018). Detecting deceit during trials: Limits in the implementation of lie detection research-A comment on Snook, McCardle, Fahmy and House. Canadian Criminal Law Review, 23(1), 97-106.

Denault, V., Plusquellec, P., Jupe, L. M., St-Yves, M., Dunbar, N. E., Hartwig, M., Sporer, S. L., RiouxTurcotte, J., Jarry, J., Walsh, D. S., Otgaar, H., Viziteu, A., Talwar, V., Keatley, D. A., Blandón-Gitlin, I., Townson, C., Deslauriers-Varin, N., Lilienfeld, S. O., Patterson, M. L., Areh, I., Allan, A., Cameron, H., Boivin, R., ten Brinke, L., Masip, J. M., Bull, R., Cyr, M., Hope, L., Strömwall, L. A., Bennett, S. J., Al Menaiya, F., Leo, R. A., Vredeveldt, A., Laforest, M., Honts, C. R., Manzanero, A. L., Mann, S., Granhag, P. A., Ask, K., Gabbert, F., Guay, J. P., Coutant, A., Hancock, J. T., Manusov, V., Burgoon, J. K., Kleinman, S. M., Wright, G., Landström, S., Freckelton, I., Vernham, Z., \& van Koppen, P. J. 
(2020). The analysis of nonverbal communication: The dangers of pseudoscience in security and justice contexts. Anuario de Psicología Jurídica, 30, 1-12.

Denault, V., Rioux-Turcotte, J., \& Tomas, F. (2019b). La spontanéité du discours, un facteur déterminant la crédibilité des témoins [The spontaneity of discourse, a determining factor of the witnesses credibility]. ScriptUM: La revue du Colloque VocUM, 2016, 3, 85-110.

DePaulo, B. M., Lindsay, J. J., Malone, B. E., Muhlenbruck, L., Charlton, K., \& Cooper, H. (2003). Cues to deception. Psychological Bulletin, 129(1), 74-112.

Diamond, S. S., Bowman, L. E., Wong, M., \& Patton, M. M. (2010). Efficiency and cost: The impact of videoconferenced hearings on bail decisions. The Journal of Criminal Law and Criminology, 100(3), 869-902.

Dinos, S., Burrowes, N., Hammond, K., \& Cunliffe, C. (2015). A systematic review of juries' assessment of rape victims: Do rape myths impact on juror decision-making? International Journal of Law, Crime and Justice, 43(1), 36-49.

Donoghue, J. (2017). The rise of digital justice: Courtroom technology, public participation and access to justice. Modern Law Review, 80(6), 995-1025.

Eagly, I. V. (2015). Remote adjudication in immigration. Northwestern University Law Review, 109(4), 933-1020.

Federman, M. (2006). On the media effects of immigration and refugee board hearings via videoconference. Journal of Refugee Studies, 19(4), 433-452.

Ford, E. B. (2006). Lie detection: Historical, neuropsychiatric and legal dimensions. International Journal of Law and Psychiatry, 29(3), 159-177.

Friedland, S. I. (1989). On common sense and the evaluation of credibility. Case Western Reserve Law Review, 40(1), 165-225.

Gerstein, J. (2020). Virus prompts first-ever arguments by phone at Supreme Court. Politico. Retrieved May 19, 2020, from https://www.politico.com/news/2020/05/04/coronavirus-supreme-court-arguments234186.

Goldin-Meadow, S., \& Alibali, M. W. (2013). Gesture's role in speaking, learning, and creating language. Annual Review of Psychology, 123, 448-453.

Hall, J. A., Horgan, T. G., \& Murphy, N. A. (2019). Nonverbal communication. Annual Review of Psychology, 70, 271-294.

Hall, J. A., \& Knapp, M. L. (2013). Nonverbal communication. Berlin: De Gruyter Mouton.

Hamilton, G., Whiting, E. A., Brubacher, S. P., \& Powell, M. (2017). The effects of face-to-face versus live video-feed interviewing on children's event reports. Legal and Criminological Psychology, 22(2), 260-273.

Harrigan, J. A. (1985). Listeners' body movements and speaking turns. Communication Research, 12(2), $233-250$.

Harrigan, J. A. (2005). Proxemics, kinesics, and gaze. In J. A. Harrigan, R. Rosenthal \& K. Scherer (Eds.), The new handbook of methods in nonverbal behavior research (pp. 137-198). New York: Oxford University Press.

Heath, H. P. (2009). Arresting and convicting the innocent: The potential role of "inappropriate" emotional display in the accused. Behavioral Sciences \& the Law, 27(3), 313-331.

Hess, U., \& Fischer, A. (2014). Emotional mimicry: Why and when we mimic emotions. Social and Personality Psychology Compass, 8(2), 45-57.

Hostetter, A. B. (2011). When do gestures communicate? A meta-analysis. Psychological Bulletin, 137(2), 297-315.

Ibrahim, H. (2020). Top trial judge says COVID-19 reveals value of remote justice. $C B C$. Retrieved May 19, 2020, from https://www.cbc.ca/news/canada/new-brunswick/remote-appearances-new-brunswickcourt-of-queens-bench-tracey-deware-1.5535054.

Johnson, M., \& Wiggins, E. (2006). Videoconferencing in criminal proceedings: Legal and empirical issues and directions for research. Law and Policy, 28(2), 211-227.

Kenniston, C. W. (2015). You may now 'call' your next witness: Allowing adult rape victims to testify via two-way video conferencing systems. Journal of High Technology Law, 16(1), 96-126.

Kleinmuntz, B., \& Szucko, J. J. (1984). Lie detection in ancient and modern times: A call for contemporary scientific study. American Psychologist, 39(7), 766-776.

Krauss, R. M., Chen, Y., \& Gottesman, R. (2000). Lexical gestures and lexical access: A process model. In D. McNeill (Ed.), Language and gesture (pp. 261-283). Cambridge: Cambridge University Press.

Leach, A. M., Ammar, N., England, D. N., Remigio, L. M., Kleinberg, B., \& Verschuere, B. J. (2016). Less is more? Detecting lies in veiled witnesses. Law and Human Behavior, 40, 401-410.

Leverick, F. (2020). What do we know about rape myths and juror decision making? The International Journal of Evidence \& Proof. https://doi.org/10.1177/1365712720923157 (Advance online publication). 
Manusov, V., \& Patterson, M. L. (Eds.). (2006). The Sage handbook of nonverbal communication. Thousand Oaks: Sage Publications.

Marr, K. (2013). The right to Skype: The due process concerns of videoconferencing at parole revocation hearings. University of Cincinnati Law Review, 81(4), 1515-1538.

Maryland v. Craig, 497 U.S. 836 (1990).

Mathieu, I. (2020). Des audiences virtuelles en plus grand nombre [More virtual audiences]. Le Nouvelliste. Retrieved May 19, 2020, from https:/www.lenouvelliste.ca/actualites/le-fil-groupe-capitales-medias/ des-audiences-virtuelles-en-plus-grand-nombre-729711ed9ced7f0b92dc4d682e033736.

Matsumoto, M., Hwang, H. C., \& Frank, M. G. (Eds.). (2016). APA handbook of nonverbal communication. Washington, D.C.: American Psychological Association.

Mattox v. United States, 156 U.S. 237 (1895).

McLachlin, B. (2020). Access to Justice: Justice in the time of social distancing. The Lawyer's Daily. Retrieved May 19, 2020, from https://www.thelawyersdaily.ca/articles/18386/access-to-justice-justicein-the-time-of-social-distancing-beverley-mclachlin.

Minzner, M. (2008). Detecting lies using demeanor, bias and context. Cardozo Law Review, 29(6), 2557-2582.

Offit, A. (2020). It's time to build a pandemic-proof, juror-friendly trial. The Hill. Retrieved May 19, 2020, from https://thehill.com/opinion/judiciary/498035-its-time-to-build-a-pandemic-proof-juror-friendlytrial.

P. (D.) v. S. (C.), 1993 CanLII 35 (SCC), [1993] 4 SCR 141.

Paciocco, D. M. (2010). Understanding the accusatorial system. Canadian Criminal Law Review, 14(3), 307-325.

Patterson, M. L. (1983). Nonverbal behaviour: A functional perspective. New York: Springer.

Patterson, M. L. (1995). A parallel process model of nonverbal communication. Journal of Nonverbal Behavior, 19(1), 3-29.

Patterson, M. L. (2011). More than words: The power of nonverbal communication. Barcelona: Editorial Aresta.

Patterson, M. L. (2019). A systems model of dyadic nonverbal interaction. Journal of Nonverbal Behavior, $43,111-132$.

Ping, R. M., \& Goldin-Meadow, S. (2010). Gesturing saves cognitive resources when talking about nonpresent objects. Cognitive Science, 34(4), 602-619.

Plusquellec, P., \& Denault, V. (2018). The 1000 most cited papers on visible nonverbal behavior: A bibliometric analysis. Journal of Nonverbal Behavior, 42(3), 347-377.

Porter, S., \& ten Brinke, L. (2009). Dangerous decisions: A theoretical framework for understanding how judges assess credibility in the courtroom. Legal and Criminological Psychology, 14(1), 119-134.

Porter, S., ten Brinke, L., \& Gustaw, C. (2010). Dangerous decisions: The impact of first impressions of trustworthiness on the evaluation of legal evidence and defendant culpability. Psychology, Crime \& Law, 16(6), 477-491.

Poulin, A. (2004). Criminal justice and videoconferencing technology: The remote defendant. Tulane Law Review, 78(4), 1089-1168.

R. v. Handy, 2002 SCC 56 (CanLII), [2002] 2 SCR 908.

R. v. J. Z. S., 2010 SCC 1 (CanLII), [2010] 1 SCR 3.

R. v. Marquard, 1993 CanLII 37 (SCC), [1993] 4 SCR 223.

R. v. N. S., 2012 SCC 72 (CanLII), [2012] 3 SCR 726.

Remland, M. (1994). The importance of nonverbal communication in the courtroom. Atlantic Journal of Communication, 2(2), 124-145.

Reynolds, M. (2020). Could Zoom jury trials become the norm during the coronavirus pandemic? $A B A$ Journal. Retrieved May 19, 2020, from https://www.abajournal.com/web/article/could-zoom-jury-trial s-become-a-reality-during-the-pandemic.

Rossano, F. (2012). Gaze in conversation. In J. Sidnell \& T. Stivers (Eds.), The handbook of conversation analysis (pp. 308-329). Chichester: Wiley.

Rowden, E. (2015). Distributed courts and legitimacy: What do we lose when we lose the courthouse? Law, Culture and the Humanities, 14(2), 263-281.

Rowden, E., \& Wallace, A. (2018). Remote judging: The impact of video links on the image and the role of the judge. International Journal of Law in Context, 14(4), 504-524.

Salyzyn, A. (2012). A new lens: Reframing the conversation about the use of video conferencing in civil trials in Ontario. Osgoode Hall Law Journal, 50(2), 429-463.

Scheppele, K. L. (1989). Foreword: Telling stories. Michigan Law Review, 87(8), 2073-2098.

Schmitz, C. (2020). Courts Zoom ahead with remote hearings due to pandemic, despite concerns of some lawyers, litigants. The Lawyer's Daily. Retrieved May 19, 2020, from https://www.thelawyersdaily.ca/ 
articles/19048/courts-zoom-ahead-with-remote-hearings-due-to-pandemic-despite-concerns-of-somelawyers-litigants.

Searcy, M., Duck, S., \& Blanck, P. (2004). Nonverbal communication in the courtroom and the "appearance” of justice. In R. E. Riggio \& R. S. Feldman (Eds.), Applications of nonverbal communication (pp. 41-61). London: Lawrence Erlbaum.

Serota, K. B. (2014). Lie to me. In T. Levine (Ed.), Encyclopedia of deception (Vol (2, pp. 600-602). Los Angeles: Sage.

Snook, B., McCardle, M. I., Fahmy, W., \& House, J. C. (2017). Assessing truthfulness on the witness stand: Eradicating deeply rooted pseudoscientific beliefs about credibility assessment by triers of fact. Canadian Criminal Law Review, 22(3), 297-306.

Strömwall, L., \& Granhag, P. A. (2003). How to detect deception? Arresting the beliefs of police officers, prosecutors and judges. Psychology, Crime and Law, 9(1), 19-36.

The Global Deception Research Team. (2006). A world of lies. Journal of Cross-Cultural Psychology, 37(1), 60-74.

Timony, J. P. (2000). Demeanor credibility. Catholic University Law Review, 49(4), 903-944.

Troville, P. V. (1939). History of lie detection. Journal of Criminal Law and Criminology, 29(6), 848-881.

Vrij, A. (2008). Detecting lies and deceit: Pitfalls and opportunities. Chichester: Wiley.

Vrij, A., \& Fisher, R. (2016). Which lie detection tools are ready for use in the criminal justice system? Journal of Applied Research in Memory and Cognition, 5(3), 302-307.

Vrij, A., \& Granhag, P. A. (2012). Eliciting cues to deception and truth: What matters are the questions asked. Journal of Applied Research in Memory and Cognition, 1(2), 110-117.

Vrij, A., \& Turgeon, J. (2018). Evaluating credibility of witnesses-Are we instructing jurors on invalid factors? Journal of Tort Law, 11(2), 231-244.

Walsh, F. M., \& Walsh, E. M. (2008). Effective processing or assembly-line justice-The use of teleconferencing in asylum removal hearings. Georgetown Immigration Law Journal, 22(2), 259-284.

Wellborn, O. G. (1990). Demeanor. Cornell Law Review, 76(5), 1075-1105.

Wilson, J. P., \& Rule, N. O. (2015). Facial trustworthiness predicts extreme criminal-sentencing outcomes. Psychological Science, 26(8), 1325-1331.

Wilson, J. P., \& Rule, N. O. (2016). Hypothetical sentencing decisions are associated with actual capital punishment outcomes: The role of facial trustworthiness. Social Psychological \& Personality Science, 7(4), 331-338.

Wise, T. A. (1845). Commentary on the Hindu system of medicine. Calcutta: Thacker and Co.

Publisher's note Springer Nature remains neutral with regard to jurisdictional claims in published maps and institutional affiliations. 